\title{
Association between diabetes and acute lymphocytic leukemia, acute myeloid leukemia, non-Hopkin lymphoma, and multiple myeloma
}

\author{
Ji Zhong Zhao ${ }^{1} \cdot$ Yu Cheng $\mathrm{Lu}^{2} \cdot$ Yan Min Wang ${ }^{2} \cdot$ Bo Lian Xiao ${ }^{2} \cdot$ Hong Yan $\mathrm{Li}^{2} \cdot$ Shao Chin Lee ${ }^{1}\left(\mathbb{0} \cdot\right.$ Li Juan Wang $^{2,3}$
}

Received: 26 April 2021 / Accepted: 20 September 2021 / Published online: 13 October 2021

(c) The Author(s) 2021

\begin{abstract}
Objective Diabetes increases the risk for cancers. However, whether it is associated with hematologic malignancies is not clear. The present study investigated the association between diabetes and acute lymphocytic leukemia (ALL), acute myeloid leukemia (ML), non-Hopkin lymphoma (NHL), and multiple myeloma (MM).

Methods Newly diagnosed adult cancer patients were recruited consecutively from our clinical database. Peoples from a local enterprise were recruited to create a small-scale population-based dataset. We compared the diabetes prevalence between the cancer patients and the local people; an increase in diabetes prevalence in the cancer patients suggests an association between diabetes and the cancer(s).

Results We found that the prevalence of diabetes was 19.7\%, 21.3\%, 12.5\%, and 12.0\% in ALL, AML, NHL, and MM, respectively, which was higher than that $(9.1 \%)$ in the local people. Despite that there were more male than female cancer patients, there were more female than male diabetic patients. The increase in diabetes prevalence occurred in ALL and NHL patients aged 18 to 39 years old as well as in AML patients over 40. In MM patients, the increase in diabetes prevalence $(18.6 \%)$ occurred only in females. Approximately $70 \%$ of the diabetic patients were undiagnosed before the diagnosis of the blood cancer. Approximately half of the pre-existing diabetic patients had anti-diabetic treatment, with over $70 \%$ of them still had poor glycemic control.
\end{abstract}

Conclusions Our results suggest that diabetes is associated with ALL, AML, NHL, and MM, at least in adult patients.

Keywords Diabetes $\cdot$ Acute lymphocytic leukemia $\cdot$ Acute myeloid leukemia $\cdot$ Non-Hopkin lymphoma $\cdot$ Multiple myeloma $\cdot$ Association

Ji Zhong Zhao and Yu Cheng Lu contributed equally to this work.

Shao Chin Lee

lee_shao@hotmail.com

Li Juan Wang

wanglj730@163.com

1 Institute of Biomedical Sciences and School of Life Sciences, Jiangsu Normal University, Xuzhou, Jiangsu, People's Republic of China

2 Central Laboratory, Linyi People's Hospital, Linyi, Shandong, China

3 Department of Hematology, Linyi People's Hospital, Linyi, Shandong, China

\section{Introduction}

Both diabetes and cancer are common non-communicable diseases with increasing prevalence. According to the Global Report on Diabetes from the World Health Organization, the prevalence of diabetes has increased from $4.7 \%$ in 1980 to $8.5 \%$ in 2014, with 422 million adults diagnosed with the disease. It is estimated that 451 million adults had diabetes in 2017, with almost half of all people living with undiagnosed diabetes [1]. Cancer is the second leading cause of death world-wide. According the statistics from the World Health Organization, cancer caused approximately 9.6 million deaths, or one in six deaths, in 2018 [2]. Diabetes and cancer cast enormous socioeconomic burden to societies. More 60 years ago, concurrent diabetes and cancer in patients had already been noted in clinical setting. However, it remained inconclusive of whether the two diseases are associated until recent decades when diabetes and cancer are highly 
prevalent. In the past decades, epidemiological studies showed that diabetes was associated with the occurrence of various cancers such as those in the liver, pancreas, stomach, colorectum, kidney, and breast. It is postulated that the prediabetic and diabetic states increase the risk for cancer. However, those presented results were not clear and sometimes conflicting [3]. In relevance to hematologic cancers, more recently, Castillo and co-workers performed a meta-analysis based on 13 case-control and 13 cohort studies, and found that diabetes was associated with NHL $(p<0.01)$, leukemia $(p=0.02)$, and possibly myeloma $(p=0.08)$ [4]. Yan et al. reported that type 2 rather than type 1 diabetes is associated with leukemia [5]. In a large insurance database in Taiwan, diabetes was found to be associated with NHL in both male and female groups [6]. Analysis on databases from Shanghai also revealed that patients with diabetes had an increased risk for NHL [7]. Wang et al. performed a meta-analysis on 35 cohort studies, and found a moderate increase in risk of NHL in types 1 and 2 diabetes, which was more significant in Asians [8]. Data from another meta-analysis supported the view that diabetes increases the risk for NHL, and further pointed out that male diabetic patients were more likely to develop NHL than females [9]. However, there are studies which showed that diabetes does not increase the overall risk for blood cancer, even in large database [10]. Diabetes might not only modify the cancer risk but also the cancer course. Indeed, diabetes and pre-diabetic state are associated with poorer prognosis of chronic lymphocytic leukemia [11], NHL [12], and myeloma [13]. On the other hand, anti-diabetic treatment, in particular by metformin, not only reduces the risk for lymphoma [14] but also improves the prognosis of lymphoma [15] and myeloma [16]. Although it is possible that metformin reduces cancer risk in diabetes by improving the metabolic profile, it has been shown to directly act on cancer cells. The compound inhibits in vitro cancer cell proliferation, migration, and invasion as well as induces apoptosis and autophagy [17], which inhibits the tumorigenesis and tumor progression [18]. In relevance to leukemia, some believed that metformin could be used to treat leukemia [19]. However, there was also evidence that metformin had neutral effect on leukemia, and yet, there was possibility that long-term use of the drug might increase the cancer risk [20].

The published meta-analyses were performed on limited number of original studies completed in different time and geographic location. The heterogeneity may affect the analysis outcome, as differences in genetic composition and life style may produce biases [4]. Anti-diabetic drugs, in particular metformin, are found to modify cancer risk, thus, including study before and after the common use of metformin in meta-analysis may produce bias. Moreover, hematologic cancers are heterogeneous and inclusion of acute lymphocytic or myeloid leukemia in analysis, rather only leukemia, might provide more informative insights. Thus, more original studies are required for a better view on the relationship between diabetes and hematologic malignancies. The present study examined the prevalence of diabetes in newly diagnosed adult patients with acute myeloid leukemia (AML), acute lymphocytic leukemia (ALL), NHL, or multiple myeloma (MM) to assess the association between diabetes and the blood malignancies. The subjects were recruited from our region and the influence of the use of metformin was minimized, which was believed to avoid the biases which might be produced by the current meta-analyses.

\section{Research design and methods}

Approval for the study was obtained from the Clinical Ethics Committee of Linyi People's Hospital which is the major regional hospital with a catchment population of 1.29 million with typical demographic and social class distributions. Most of the inhabitants are eastern Chinese in origin. Because of the lack of a long-term health care financing policy, the majority of people in this region do not have medical insurance for chronic diseases, such as cancer and diabetes. As a result, most of these patients seek medical care at the public hospitals where only nominal fees are charged. The cancer patients aged from 18 years or above, who were hospitalized between 2015 and 2020, were consecutively recruited. We recruited 1050 local people to create a small-scale population-based survey dataset in 2019 .

AML, ALL, and NHL were diagnosed and classified according to the 2016 WHO criteria [21, 22]. MM was diagnosed and classified according to the criteria by the 2014 International Myeloma Working Group [23]. Fasting blood samples were taken for biochemical assays. For the cancer patients, blood samples were taken on the diagnosis of cancer before any clinical treatment. Diabetes was evidenced when fasting plasma glucose $\geq 126 \mathrm{mg} / \mathrm{dL}(7.0 \mathrm{mmol} / \mathrm{L})$ [24]. Those with diabetes history were also included in the diabetes group, even though they had achieved satisfactory glycemic control. In the study, the patients with AML, ALL, NHL, and MM were 622, 416, 789, and 392, respectively. The subjects randomly recruited outside the hospital for the estimation of diabetes prevalence were 1052. Soon after admission of the patients, fasting blood samples were taken to the biochemical analyses. For the subjects recruited from outside the hospital, who were involved in the survey for the estimation of diabetes prevalence, fasting blood samples were taken for the determination of the metabolic profile.

Fasting blood glucose levels were measured using a hexokinase method. Plasma levels of total cholesterol and triglyceride were assayed enzymatically using commercially available reagents (Beckmancoulter; Beckman Instrument, USA). HDL-cholesterol was detected using the selective 
Table 1 Demographic data of the adult patients with ALL, AML, NHL, or MM

\begin{tabular}{|c|c|c|c|c|c|c|}
\hline \multirow[t]{2}{*}{ Cancer type } & \multirow[t]{2}{*}{ Clinical parameter } & \multicolumn{5}{|c|}{ Adult patients with ALL, AML, NHL, or MM } \\
\hline & & Overall $(n=2219)$ & Men $(n=1266)$ & Women $(n=911)$ & Non-diabetic & Diabetic \\
\hline \multirow[t]{6}{*}{ AML } & Age $(95 \% \mathrm{CI})$ & $\begin{array}{l}51.71(50.48 \text { to } \\
52.93)\end{array}$ & $\begin{array}{l}52.43(50.75 \text { to } \\
54.12)\end{array}$ & $\begin{array}{l}50.89 \text { (49.11 to } \\
52.66)\end{array}$ & $\begin{array}{l}50.39 \text { (48.98 to } \\
51.81)\end{array}$ & $\begin{array}{l}57.23(55.00 \text { to } \\
59.47)^{* * *}\end{array}$ \\
\hline & $\begin{array}{l}\text { Fasting plasma } \\
\text { glucose }(\mathrm{mmol} / \mathrm{L}) \\
(95 \% \mathrm{CI})\end{array}$ & $6.33(6.15$ to 6.51$)$ & $6.26(6.01$ to 6.51$)$ & $6.40(6.14$ to 6.67$)$ & $5.52(5.45$ to 5.58$)$ & $\begin{array}{c}9.63(9.04 \text { to } \\
10.22)^{* * *}\end{array}$ \\
\hline & $\begin{array}{l}\text { Total cholesterol } \\
(\mathrm{mmol} / \mathrm{L})(95 \% \\
\mathrm{CI})\end{array}$ & 3.71 (3.60 to 3.82$)$ & 3.57 (3.43 to 3.72$)$ & $3.88(3.71 \text { to } 4.05)^{*}$ & $3.73(3.60$ to 3.85$)$ & 3.63 (3.37 to 3.89$)$ \\
\hline & $\begin{array}{l}\text { Low-density lipo- } \\
\text { protein }(\mathrm{mmol} / \mathrm{L}) \\
(95 \% \mathrm{CI})\end{array}$ & $2.31(2.23$ to 2.40$)$ & $2.23(2.12$ to 2.34$)$ & $2.42(2.29 \text { to } 2.55)^{*}$ & $2.32(2.23$ to 2.42$)$ & $2.26(2.06$ to 2.46$)$ \\
\hline & $\begin{array}{l}\text { High-density lipo- } \\
\text { protein }(\mathrm{mmol} / \mathrm{L}) \\
(95 \% \mathrm{CI})\end{array}$ & $0.89(0.86$ to 0.92$)$ & $0.86(0.83$ to 0.90$)$ & $0.93(0.87 \text { to } 0.97)^{*}$ & $0.91(0.86$ to 0.94$)$ & $0.83(0.78$ to 0.88$)$ \\
\hline & $\begin{array}{l}\text { Triglycerides } \\
\quad(\mathrm{mmol} / \mathrm{L})(95 \% \\
\mathrm{CI})\end{array}$ & $1.51(1.41$ to 1.61$)$ & $1.40(1.29$ to 1.52$)$ & $1.65(1.48 \text { to } 1.82)^{*}$ & $1.50(1.39$ to 1.62$)$ & 1.57 (1.38 to 1.76$)$ \\
\hline \multirow[t]{6}{*}{ ALL } & Age $(95 \% \mathrm{CI})$ & $\begin{array}{l}41.98 \text { (38.99 to } \\
44.97)\end{array}$ & $\begin{array}{l}43.29 \text { (38.96 to } \\
47.62)\end{array}$ & $\begin{array}{l}40.38 \text { (36.22 to } \\
44.54)\end{array}$ & $\begin{array}{l}41.00(37.82 \text { to } \\
44.18)\end{array}$ & $\begin{array}{l}47.57 \text { (38.19 to } \\
56.95)\end{array}$ \\
\hline & $\begin{array}{l}\text { Fasting plasma } \\
\text { glucose }(\mathrm{mmol} / \mathrm{L}) \\
(95 \% \mathrm{CI})\end{array}$ & $5.70(5.34$ to 6.01$)$ & $5.82(5.29$ to 6.35$)$ & $5.56(5.06$ to 6.06$)$ & $5.11(4.94$ to 5.27$)$ & $\begin{array}{c}9.28(8.04 \text { to } \\
10.52)^{* * *}\end{array}$ \\
\hline & $\begin{array}{l}\text { Total cholesterol } \\
(\mathrm{mmol} / \mathrm{L})(95 \% \\
\mathrm{CI})\end{array}$ & $4.08(3.77$ to 4.39$)$ & $4.14(3.72$ to 4.56$)$ & $4.02(3.54$ to 4.50$)$ & $4.08(3.73$ to 4.44$)$ & $4.13(3.28$ to 4.98$)$ \\
\hline & $\begin{array}{l}\text { Low-density lipo- } \\
\text { protein }(\mathrm{mmol} / \mathrm{L}) \\
(95 \% \mathrm{CI})\end{array}$ & $2.60(2.36$ to 2.84$)$ & 2.67 (2.38 to 2.96$)$ & $2.54(2.16$ to 2.92$)$ & $2.59(2.32$ to 2.86$)$ & $2.74(2.11$ to 3.37$)$ \\
\hline & $\begin{array}{l}\text { High-density lipo- } \\
\text { protein }(\mathrm{mmol} / \mathrm{L}) \\
(95 \% \mathrm{CI})\end{array}$ & $0.88(0.80$ to 0.96$)$ & $0.84(0.72$ to 0.96$)$ & $0.91(0.81$ to 1.02$)$ & $0.90(0.81$ to 0.99$)$ & $0.81(0.59$ to 1.03$)$ \\
\hline & $\begin{array}{l}\text { Triglycerides } \\
(\mathrm{mmol} / \mathrm{L})(95 \% \\
\mathrm{CI})\end{array}$ & $1.92(1.40$ to 2.43$)$ & $1.66(1.5$ to 1.8$)$ & $1.74(1.53$ to 1.93$)$ & $1.66(1.52$ to 1.80$)$ & $1.83(1.52$ to 2.14$)$ \\
\hline \multirow[t]{6}{*}{ NHL } & Age $(95 \% \mathrm{CI})$ & $\begin{array}{l}57.63(56.22 \text { to } \\
59.03)\end{array}$ & $\begin{array}{l}57.56(55.78 \text { to } \\
59.35)\end{array}$ & $\begin{array}{l}57.73(55.43 \text { to } \\
60.04)\end{array}$ & $\begin{array}{l}57.43(55.88 \text { to } \\
58.98)\end{array}$ & $58.84(55.58$ to 62.1$)$ \\
\hline & $\begin{array}{l}\text { Fasting plasma } \\
\text { glucose }(\mathrm{mmol} / \mathrm{L}) \\
(95 \% \mathrm{CI})\end{array}$ & $5.71(5.53$ to 5.88$)$ & $5.64(5.43$ to 5.84$)$ & $5.83(5.51$ to 6.16$)$ & $5.15(5.08$ to 5.23$)$ & $\begin{array}{c}9.13(8.46 \text { to } \\
9.80)^{* * *}\end{array}$ \\
\hline & $\begin{array}{l}\text { Total cholesterol } \\
\text { (mmol/L) }(95 \% \\
\text { CI) }\end{array}$ & $4.16(4.00$ to 4.34$)$ & 3.99 (3.78 to 4.20$)$ & $4.50(4.25 \text { to } 4.75)^{*}$ & $4.21(4.04$ to 4.39$)$ & $3.74(3.25$ to 4.23$)$ \\
\hline & $\begin{array}{l}\text { Low-density lipo- } \\
\text { protein }(\mathrm{mmol} / \mathrm{L}) \\
(95 \% \mathrm{CI})\end{array}$ & $2.69(2.58$ to 2.80$)$ & $2.62(2.48$ to 2.76$)$ & $2.82(2.64$ to 3.00$)$ & $2.71(2.60$ to 2.83$)$ & $2.49(2.17$ to 2.81$)$ \\
\hline & $\begin{array}{l}\text { High-density lipo- } \\
\text { protein }(\mathrm{mmol} / \mathrm{L}) \\
(95 \% \mathrm{CI})\end{array}$ & 1.11 (1.04 to 1.18$)$ & $1.11(1.01$ to 1.21$)$ & $1.10(1.01$ to 1.20$)$ & 1.14 (1.06 to 1.22$)$ & $0.83(0.73 \text { to } 0.93)^{*}$ \\
\hline & $\begin{array}{l}\text { Triglycerides } \\
(\mathrm{mmol} / \mathrm{L})(95 \% \\
\mathrm{CI})\end{array}$ & $1.40(1.28$ to 1.52$)$ & $1.44(1.27$ to 1.60$)$ & $1.33(1.17$ to 1.49$)$ & $1.41(1.28$ to 1.54$)$ & $1.30(1.00$ to 1.61$)$ \\
\hline
\end{tabular}


Table 1 (continued)

\begin{tabular}{|c|c|c|c|c|c|c|}
\hline \multirow[t]{2}{*}{ Cancer type } & \multirow[t]{2}{*}{ Clinical parameter } & \multicolumn{5}{|c|}{ Adult patients with ALL, AML, NHL, or MM } \\
\hline & & Overall $(n=2219)$ & $\operatorname{Men}(n=1266)$ & Women $(n=911)$ & Non-diabetic & Diabetic \\
\hline \multirow[t]{6}{*}{ MM } & Age $(95 \% \mathrm{CI})$ & $\begin{array}{l}61.69(60.73 \text { to } \\
62.65)\end{array}$ & $\begin{array}{l}61.24(59.91 \text { to } \\
62.57)\end{array}$ & $\begin{array}{l}62.34(60.97 \text { to } \\
63.7)\end{array}$ & $61.75(60.7$ to 62.8$)$ & $\begin{array}{l}61.28(58.92 \text { to } \\
63.63)\end{array}$ \\
\hline & $\begin{array}{l}\text { Fasting plasma } \\
\text { glucose }(\mathrm{mmol} / \mathrm{L}) \\
(95 \% \mathrm{CI})\end{array}$ & 5.77 (5.57 to 5.97$)$ & $5.79(5.50$ to 6.07$)$ & $5.74(5.47$ to 6.01$)$ & $5.25(5.18$ to 5.33$)$ & $\begin{array}{c}9.54(8.46 \text { to } \\
10.63)^{* * *}\end{array}$ \\
\hline & $\begin{array}{l}\text { Total cholesterol } \\
(\mathrm{mmol} / \mathrm{L})(95 \% \\
\mathrm{CI})\end{array}$ & $3.82(3.63$ to 4.01$)$ & $3.62(3.41$ to 3.84$)$ & $4.12(3.76 \text { to } 4.45)^{*}$ & $3.84(3.63$ to 4.04$)$ & $3.71(3.20$ to 4.21$)$ \\
\hline & $\begin{array}{l}\text { Low-density lipo- } \\
\text { protein }(\mathrm{mmol} / \mathrm{L}) \\
(95 \% \mathrm{CI})\end{array}$ & 2.34 (2.19 to 2.49$)$ & $2.20(2.03$ to 2.36$)$ & $2.55(2.28 \text { to } 2.81)^{*}$ & $2.35(2.19$ to 2.51$)$ & $2.24(1.88$ to 2.61$)$ \\
\hline & $\begin{array}{l}\text { High-density lipo- } \\
\text { protein }(\mathrm{mmol} / \mathrm{L}) \\
(95 \% \mathrm{CI})\end{array}$ & $0.96(0.92$ to 1.01$)$ & $0.94(0.88$ to 1.00$)$ & $0.99(0.93$ to 1.06$)$ & $0.97(0.92$ to 1.01$)$ & $0.90(0.74$ to 1.06$)$ \\
\hline & $\begin{array}{l}\text { Triglycerides } \\
(\mathrm{mmol} / \mathrm{L})(95 \% \\
\mathrm{CI})\end{array}$ & $1.40(1.28$ to 1.51$)$ & $1.32(1.16$ to 1.47$)$ & 1.51 (1.33 to 1.69$)$ & 1.35 (1.24 to 1.47$)$ & $1.74(1.20 \text { to } 2.27)^{*}$ \\
\hline
\end{tabular}

Date are expressed in mean (95\% confidence interval)

${ }^{*} p<0.05$; *** $p<0.001$, compared between males and females or diabetic and non-diabetic patients

inhibition method. LDL-cholesterol was measured using a surfactant method. All biochemical variables were measured using an autoanalyzer (Beckmancoulter AU5821; Beckman Instrument, USA) at the biochemical laboratory of the Linyi People's Hospital. Fasting blood samples were centrifuged (3000 rpm, $10 \mathrm{~min}$ ) to obtain serum fraction. Exactly $1.2-\mu \mathrm{l}$ serum was loaded onto the automatic analyzing machine each time, separately, for the quantification of glucose, HDL-C, LDL-C, and total cholesterol, using the primary and secondary wavelengths at $340 \mathrm{~nm}$ and $660 \mathrm{~nm}, 600 \mathrm{~nm}$ and $700 \mathrm{~nm}$, and $540 \mathrm{~nm}$ and $600 \mathrm{~nm}$, respectively. Exactly 1.6- $\mu \mathrm{l}$ serum was loaded to determine the level of triglyceride at the primary and secondary wavelengths at 660 and 800 respectively.

All data for continuous variables are expressed as mean (95\% confidence interval) and were assessed using Student's $t$-test. $\chi^{2}$ test was performed for analyzing proportions. The statistical analyses were performed using the Statistical Package for Social Sciences version 26 (SPSS, Chicago). A $p$ value $<0.05$ was considered to be statistically significant. We also confirmed all methods were performed in accordance with the relevant guidelines and regulations.

\section{Results}

Table 1 shows the clinical data of the patients with ALL, AML, NHL, or MM. The prevalence of diabetes was $19.7 \%$, $21.3 \%, 12.5 \%$, and $12.0 \%$ in ALL, AML, NHL, and MM patients, respectively (Table 2; Fig. 1), which was higher than that $(9.1 \%)$ in our local people and that $(8.7 \%$ and $9.7 \%$ ) in two recent national surveys (Table 3; Fig. 2). As shown in Table 2 and Fig. 1, there were more male than female patients in all the four cancer groups, with the male to female ratio of $1.24: 1,1.13: 1,1.74: 1$, and $1.43: 1$ in the ALL, AML, NHL, and MM patients, respectively. In contrast, the prevalence of diabetes was higher in the female than male cancer patients, although the difference did not reach a statistically significant level upon our sample size. Moreover, the increase in diabetes prevalence occurred in ALL and NHL patients aged 18 to 39 years old, and in AML patients aged over 40 . In MM patients, the increase in diabetes prevalence $(18.6 \%)$ occurred in female patients, rather than in a specific age group. In the cancer patients, approximately $70 \%$ of the diabetes cases were undiagnosed before the diagnosis of the cancer. Approximately half of the preexisting diabetic patients had anti-diabetic treatment, with over $70 \%$ of them still had poor glycemic control.

\section{Discussion}

AML is the most common leukemia in adults, with more male than female patients [26], which accounts for around $1.3 \%$ of all new cancer cases in the USA in 2015 [27]. The development of ALL shows a bi-model feature, with one peak at children and the other at around 50 years old. In a Chinese population, the incidence of ALL was 0.63 per 


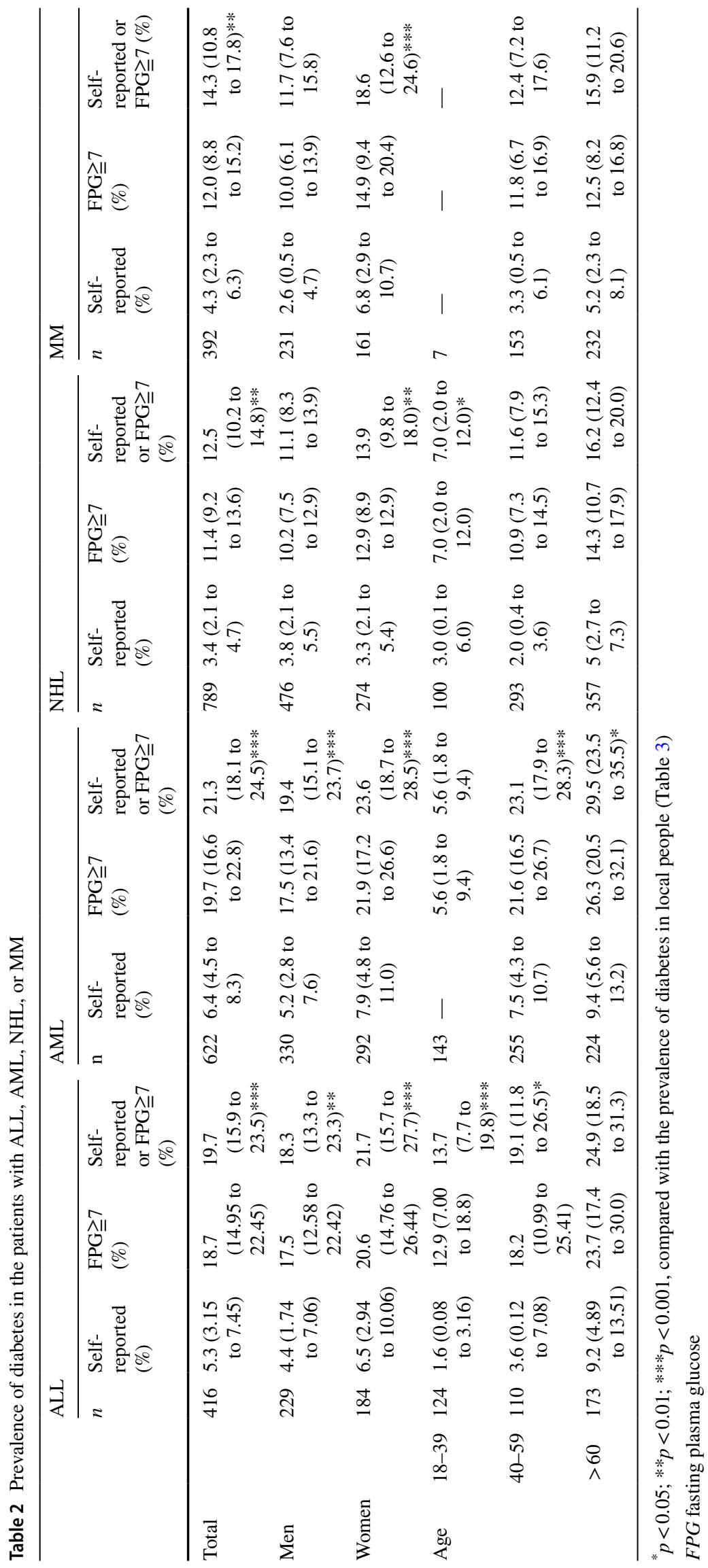



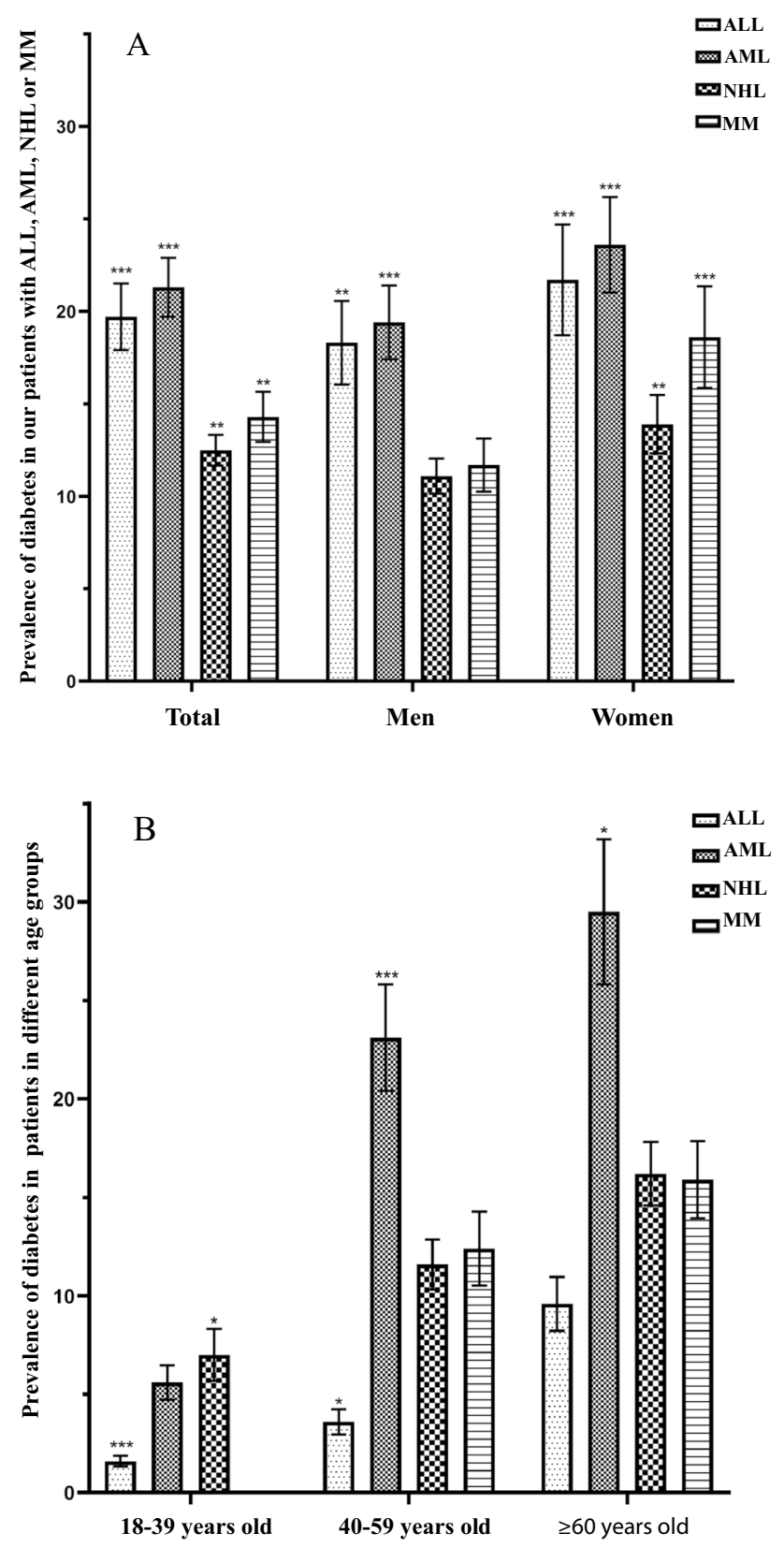

Fig. 1 Prevalence of diabetes in our adult patients with ALL, AML, NHL, or MM. A The prevalence of diabetes in all patients as well as male and female patients. B The prevalence of diabetes in our patients according to different age groups. ${ }^{*} p<0.05$, $* * * p<0.001$, compare to the prevalence of diabetes in our survey in our local population and those reported in two national surveys (Fig. 2). The diagnosis criteria of diabetes used in our study and the national surveys are the same

100,000 people, with the male:female ratio of approximately 1.5:1 [28]. Although AML in adults is less common compared with ALL, it represents a devastating clinical condition. The increase in prevalence and improved therapy

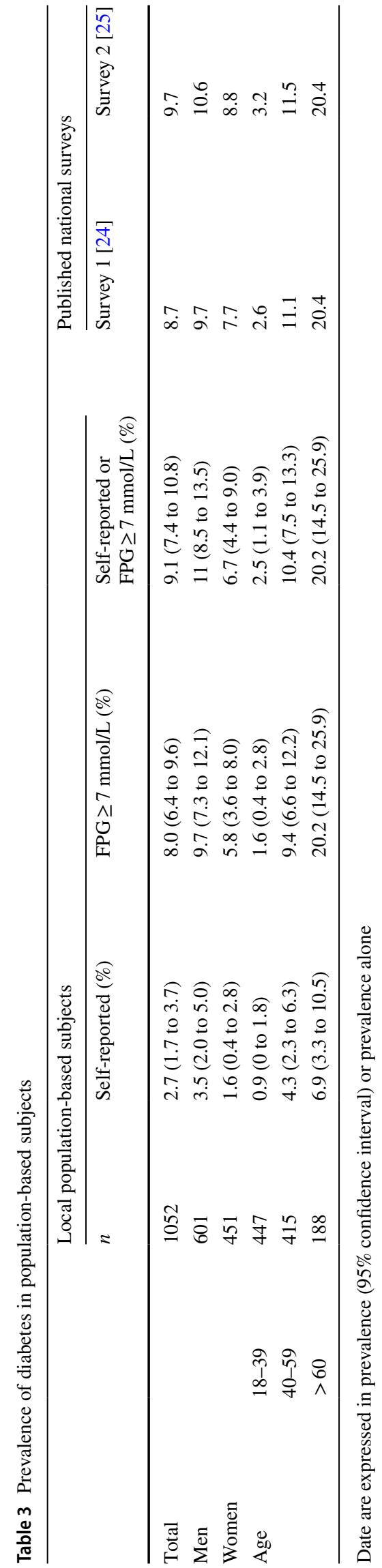




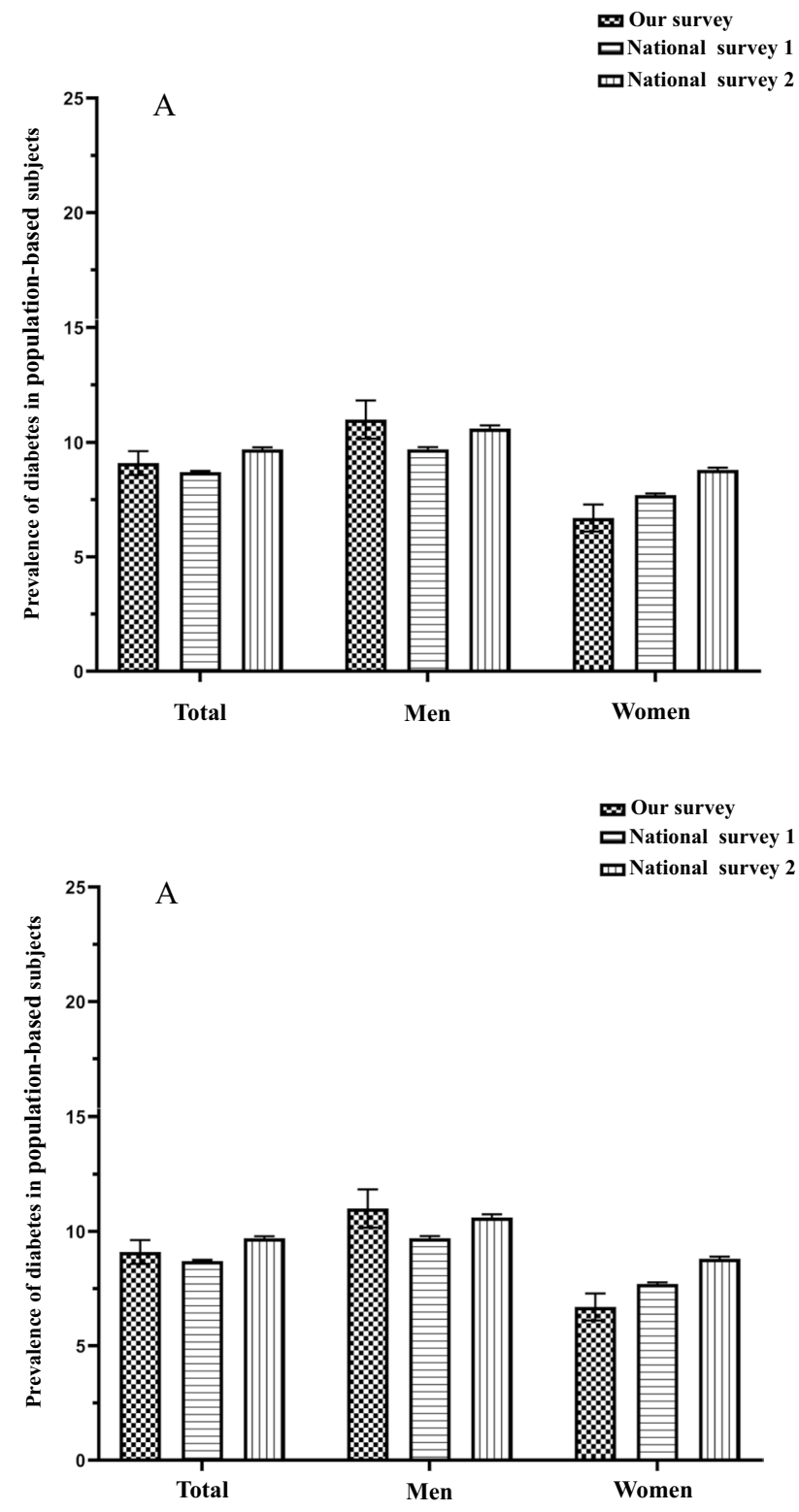

Fig. 2 The prevalence of diabetes in our local population and in national surveys. A The prevalence of diabetes in our local population and those reported in the two national surveys. B The prevalence of diabetes in our local population and reported in a national survey according to the age groups. There was no significant difference in the prevalence of diabetes between our local population and the population recruited for the national surveys. The numbers of male and female subjects were available from the national survey 1 but not 2; thus, only the data of diabetes prevalence of diabetes in different age groups from the national survey 1 were shown and used in the statistical analysis

outcome has increased the number of patients with NHL. From a population-based database in Taiwan, the incidence of MM is estimated to be 1.83 per 100,000 people, with more male than female patients [29]. Despite that diabetes is now known to increase the risk for various cancers, whether the metabolic disease is associated with these hematologic malignancies still remains inconclusive. Our results showed that diabetes prevalence was increased in all of the patients with ALL, AML, NHL, or MM, suggesting that diabetes is associated with the four hematologic malignancies, in particular ALL and AML. In our study, most diabetes cases were undiagnosed before the diagnosis of the blood cancer, and majority of the patients with diabetes history had poor glycemic control, which indicates that our results are not confounded by anti-diabetic treatment, but may truly reflect the impact of metabolic disorder on the risk for the blood cancers. The people living with undiagnosed diabetes are at serious risk for developing cancer, including the hematologic malignancies.

Similar to the previous observations in the literature, we found that there were more male than female patients with the blood cancers, suggesting an increased susceptibility to the blood cancers in males. In contract, in the ALL, AML, NHL, and MM patients, there were more female than male diabetic patients, although the difference did not reach a statistically significant level upon the sample size. However, the female:male ratio in the diabetic patients was significantly increased compared to that in the non-diabetic cancer patients $(p=0.004)$, if patients with ALL, AML, NHL, or MM were combined. In a report on pancreatic cancer, the authors showed that the number of female diabetic patients was significantly higher than that of diabetic males $(p=0.008)$ [30]. Thus, the association of diabetes with cancer might have a female preponderance.

Commonly, researchers analyze cancer prevalence in diabetes to assess the impact of diabetes on cancer risk. In the present study, we analyzed the diabetes prevalence in cancer patients to reflect the disease association. Such strategy, although uncommon, did have been employed by investigators [30], which can also produce informative data. There are possible biases in our analysis. Firstly, the sample size is limited, which may not be adequate for revealing the disease association correctly, and may be able for fully documenting the characters of the association (i.e., female preponderance).

Whether and how diabetes promotes cancer development remains unknown. Overweight and lifestyle were both confounding factors, and high glucose and insulin use were speculated to favor tumorigenesis via various mechanisms. TET2, a tumor suppressor which can repress leukemia progression, is a substrate of the AMP-activated kinase (AMPK) which phosphorylates TET2 at serine 99 and thereby stabilizes it for tumor repression. However, in the case of diabetes, increased glucose level impedes AMPK-mediated phosphorylation at serine 99 , which results in the destabilization and degradation of TET2, which links diabetes to cancer [31]. In genetically modified experimental models, centrosome amplification is sufficient to cause tumorigenesis. 
It would be interesting to investigate whether centrosome amplification is a biological link between diabetes and blood malignancies, since centrosome amplification occurs in cells with centrosome amplification can form tumors in recipient animals and mice spontaneously develop tumors, suggesting that centrosome amplification can cause tumorigenesis. Centrosome amplification occurs in myelodysplastic syndromes [32], leukemia [33], lymphoma [34], and myeloma [35]. Diabetes lowers the level of leukemia inhibitory factor that can induce differentiation and inhibits proliferation of leukemic cells [36, 37], which is also candidate mechanism. Alternatively, the association between diabetes and leukemia might reflect their shared etiological mechanisms rather than a promoting effect of diabetes on tumorigenesis. Let-7 is a family of non-coding microRNAs that include Let-7a to g, Let-7i, and miR-98. In leukemia, several let-7 family members (let-7a to f) were upregulated and associated with a high grate of the cancer [38, 39]. On the other hand, let-7 can act as an essential factor to regulate glucose metabolism [40]. Lin28/let-7 is a self-renewal system [41], in which let-7 is inhabited by Lin28. In muscle cells, both Lin28a knockdown or let-7 over-expression result in insulin resistance and impaired glucose [40]. Thus, Let- 7 might be a common etiological factor for diabetes and leukemia.

\section{Conclusion}

Our results showed that many diabetic patients remained undiagnosed with poor glycemic profile. Diabetes was over presented in patients with ALL, AML, NHL, and MM, which was more obvious in the female than that in the male cancer patients. It is suggested that diabetes increases the risk for these hematologic cancers in adults, in particular in the females.

Acknowledgements We are grateful to Linyi People's Hospital for approval for this study, and to all individuals who agreed to provide data.

Author contribution J.Z. Zhao, YC Lu, Y.M. Wang, B.L. Xiao, and H.Y. Li collected the data. J.Z. Zhao and Y.C. Lu prepared Tables 1, 2, and 3. S.C. Lee and L.J. Wang applied for research grants, designed the study, interpreted the data, and wrote the manuscript. All authors reviewed the manuscript.

Funding The study was supported by grants to Dr. Shao Lee (No. 9212418120 and 9212430401$)$.

Data availability The data are available from the corresponding authors.

\section{Declarations}

Statement of ethics Approval for the study was obtained from the Clinical Ethics Committee of Linyi People's Hospital. This research is strictly complying with the guidelines for human studies and was conducted ethically in accordance with the World Medical Association Declaration of Helsinki. All of the patients and their guardians have given their written informed consent.

Conflict of interest The authors declare no competing interests.

Open Access This article is licensed under a Creative Commons Attribution 4.0 International License, which permits use, sharing, adaptation, distribution and reproduction in any medium or format, as long as you give appropriate credit to the original author(s) and the source, provide a link to the Creative Commons licence, and indicate if changes were made. The images or other third party material in this article are included in the article's Creative Commons licence, unless indicated otherwise in a credit line to the material. If material is not included in the article's Creative Commons licence and your intended use is not permitted by statutory regulation or exceeds the permitted use, you will need to obtain permission directly from the copyright holder. To view a copy of this licence, visit http://creativecommons.org/licenses/by/4.0/.

\section{References}

1. Cho NH, Shaw JE, Karuranga S, et al. IDF diabetes atlas: global estimates of diabetes prevalence for 2017 and projections for 2045. Diabetes Res Clin Pract. 2018;138:271-81.

2. WHO. Cancer overview. https://www.who.int/health-topics/can$\mathrm{cer \# tab}=\mathrm{tab} \_1$

3. Abudawood M. Diabetes and cancer: a comprehensive review. J Res Med Sci. 2019;24:94.

4. Castillo JJ, Mull N, Reagan JL, et al. Increased incidence of nonHodgkin lymphoma, leukemia, and myeloma in patients with diabetes mellitus type 2 : a meta-analysis of observational studies. Blood. 2012;119:4845-50.

5. Yan P, Wang Y, Fu T, et al. The association between type 1 and 2 diabetes mellitus and the risk of leukemia: a systematic review and meta-analysis of 18 cohort studies. Endocr J. 2021;68:281-9.

6. Tseng $\mathrm{CH}$. Diabetes and non-Hodgkin's lymphoma: analyses of prevalence and annual incidence in 2005 using the National Health Insurance database in Taiwan. Ann Oncol. 2012;23:153-8.

7. Yang WS, Li HL, Xu HL, et al. Type 2 diabetes and the risk of non-Hodgkin's lymphoma: a report from two population-based cohort studies in China. Eur J Cancer Prev. 2016;25:149-54.

8. Wang Y, Liu X, Yan P, et al. Association between type 1 and type 2 diabetes and risk of non-Hodgkin's lymphoma: a meta-analysis of cohort studies. Diabetes Metab. 2020;46:8-19.

9. Xu J, Wang T. Association of diabetes mellitus with non-Hodgkin lymphoma risk: a meta-analysis of cohort studies. Hematology. 2019;24:527-32.

10. Khan AE, Gallo V, Linseisen J, et al. Diabetes and the risk of non-Hodgkin's lymphoma and multiple myeloma in the European Prospective Investigation into Cancer and Nutrition. Haematologica. 2008;93:842-50.

11. Gao R, Man TS, Liang JH, et al. Diabetes mellitus is associated with inferior prognosis in patients with chronic lymphocytic leukemia: a propensity score-matched analysis. Cancer Res Treat. 2020;52:189-206.

12. Lin SY, Hsieh MS, Chen LS, et al. Diabetes mellitus associated with the occurrence and prognosis of non-Hodgkin's lymphoma. Eur J Cancer Prev. 2007;16:471-8. 
13. Chou YS, Yang CF, Chen HS, et al. Pre-existing diabetes mellitus in patients with multiple myeloma. Eur J Haematol. 2012;89:320-7.

14. Tseng $\mathrm{CH}$. Metformin is associated with a lower risk of nonHodgkin lymphoma in patients with type 2 diabetes. Diabetes Metab. 2019;45:458-64.

15. Wynn A, Vacheron A, Zuber J, et al. Metformin associated with increased survival in type 2 diabetes patients with pancreatic cancer and lymphoma. Am J Med Sci. 2019;358:200-3.

16. Wu W, Merriman K, Nabaah A, et al. The association of diabetes and anti-diabetic medications with clinical outcomes in multiple myeloma. Br J Cancer. 2014;111:628-36.

17. Zou G, Bai J, Li D, et al. Effect of metformin on the proliferation, apoptosis, invasion and autophagy of ovarian cancer cells. Exp Ther Med. 2019;18:2086-94.

18. De Santi M, Baldelli G, Diotallevi A, et al. Metformin prevents cell tumorigenesis through autophagy-related cell death. Sci Rep. 2019;9:66.

19. Biondani G, Peyron JF. Metformin, an anti-diabetic drug to target leukemia. Front Endocrinol (Lausanne). 2018;9:446.

20. Tseng CH. Metformin use and leukemia risk in patients with type 2 diabetes mellitus. Front Endocrinol (Lausanne). 2020;11:541090.

21. Arber DA, Orazi A, Hasserjian R, et al. The 2016 revision to the World Health Organization classification of myeloid neoplasms and acute leukemia. Blood. 2016;127:2391-405.

22. Swerdlow SH, Campo E, Pileri SA, et al. The 2016 revision of the World Health Organization classification of lymphoid neoplasms. Blood. 2016;127:2375-90.

23. Rajkumar SV, Dimopoulos MA, Palumbo A, et al. International Myeloma Working Group updated criteria for the diagnosis of multiple myeloma. Lancet Oncol. 2014;15:e538-548.

24. Li Y, Teng D, Shi X, et al. Prevalence of diabetes recorded in mainland China using 2018 diagnostic criteria from the American Diabetes Association: national cross sectional study. BMJ. 2020;369:m997.

25. Yang W, Lu J, Weng J, et al. Prevalence of diabetes among men and women in China. N Engl J Med. 2010;362:1090-101.

26. Shysh AC, Nguyen LT, Guo M, Vaska M, Naugler C, RashidKolvear F. The incidence of acute myeloid leukemia in Calgary, Alberta, Canada: a retrospective cohort study. BMC Public Health. 2017; 18:94.

27. Tamamyan G, Kadia T, Ravandi F, et al. Frontline treatment of acute myeloid leukemia in adults. Crit Rev Oncol Hematol. 2017;110:20-34.

28. Clinical Collaborative Group of Fujian Medical Association Hematological B. Incidence of newly diagnosed adult acute leukemia in Fujian province from 2011 to 2012. Zhonghua Xue Ye Xue Za Zhi. 2015;36:733-8.
29. Chen JH, Chung CH, Wang YC, Hsu SN, Huang WY, Chien WC. Prevalence and mortality-related factors of multiple myeloma in Taiwan. Plos One. 2016;11:e0167227.

30. Trna J, Dite P, Adamcova A, Crawford BJ, Hermanova M. Diabetes mellitus in pancreatic cancer patients in the Czech Republic: sex differences. Exp Diabetes Res. 2012;2012:414893.

31. Wu D, Hu D, Chen H, et al. Glucose-regulated phosphorylation of TET2 by AMPK reveals a pathway linking diabetes to cancer. Nature. 2018;559:637-41.

32. Nolte F, Giehl M, Haass W, et al. Centrosome aberrations in bone marrow cells from patients with myelodysplastic syndromes correlate with chromosomal instability. Ann Hematol. 2013;92:1325-33.

33. Neben K, Giesecke C, Schweizer S, Ho AD, Kramer A. Centrosome aberrations in acute myeloid leukemia are correlated with cytogenetic risk profile. Blood. 2003;101:289-91.

34. Kramer A, Schweizer S, Neben K, et al. Centrosome aberrations as a possible mechanism for chromosomal instability in nonHodgkin's lymphoma. Leukemia. 2003;17:2207-13.

35. Kryukova E, Kryukov F, Hajek R. Centrosome amplification and clonal evolution in multiple myeloma: short review. Crit Rev Oncol Hematol. 2016;98:116-21.

36. Zarei R, Nikpour P, Rashidi B, Eskandari N, Aboutorabi R. Evaluation of diabetes effects on the expression of leukemia inhibitory factor and vascular endothelial growth factor a genes and proteins at the time of endometrial receptivity after superovulation in rat model. Adv Biomed Res. 2019;8:66.

37. Gearing DP, Gough NM, King JA, et al. Molecular cloning and expression of cDNA encoding a murine myeloid leukaemia inhibitory factor (LIF). Embo j. 1987;6:3995-4002.

38. Garzon R, Volinia S, Liu CG, et al. MicroRNA signatures associated with cytogenetics and prognosis in acute myeloid leukemia. Blood. 2008;111:3183-9.

39. Marcucci G, Mrozek K, Radmacher MD, Garzon R, Bloomfield $\mathrm{CD}$. The prognostic and functional role of microRNAs in acute myeloid leukemia. Blood. 2011;117:1121-9.

40. Zhu H, Shyh-Chang N, Segre AV, et al. The Lin28/let-7 axis regulates glucose metabolism. Cell. 2011;147:81-94.

41. Copley MR, Babovic S, Benz C, et al. The Lin28b-let-7-Hmga2 axis determines the higher self-renewal potential of fetal haematopoietic stem cells. Nat Cell Biol. 2013;15:916-25.

Publisher's note Springer Nature remains neutral with regard to jurisdictional claims in published maps and institutional affiliations. 